\title{
Delayed presentation of posttraumatic diaphragmatic hernia
}

\author{
Geç bulgu veren travmatik diyafram hernileri
}

\author{
İsmail OKAN, ${ }^{1}$ Gürhan BAŞ, ${ }^{2}$ Sedat ZIYYADE, ${ }^{3}$ Orhan ALIMOĞLU, ${ }^{2}$ \\ Ramazan ERYILMAZ, ${ }^{2}$ Deniz GÜZEY, ${ }^{2}$ Aydın ZILAN ${ }^{2}$
}

\section{BACKGROUND}

Missed diaphragmatic injuries after trauma may present with herniation of intraabdominal organs into the thoracic cavity. We aimed to review our patients who presented with delayed posttraumatic diaphragmatic hernia.

\section{METHODS}

A retrospective review of the medical records of patients with delayed diagnosis of posttraumatic diaphragmatic hernia between 2001 and 2009 was performed.

\section{RESULTS}

Ten patients with a mean age of 44.3 years were included. Six patients were female. Blunt injuries (n: 7) were more common. Mean duration between trauma and presentation to the hospital was 5.9 years ( 4 months - 19 years). Nine patients had left-sided diaphragmatic hernia. All patients had chest X-ray and most were diagnostic (n: 8). Additional diagnostic imaging with computerized tomography (CT) and magnetic resonance (MR) was used in seven patients. For the repair, laparotomy incision was chosen for seven patients and thoracotomy incision for two patients. One patient underwent left thoracoabdominal approach. Mesh repair was used in seven patients. Postoperative mean hospitalization was 10.6 days. Empyema and atelectasis were the morbidities in one patient. No postoperative mortality was detected.

\section{CONCLUSION}

Delayed presentation of posttraumatic diaphragmatic hernia is a serious challenge for trauma surgeons. Prompt diagnosis and treatment prevent serious morbidity and mortality associated with complications such as gangrene and/or perforation of the herniated organ.

Key Words: Diaphragmatic hernia; delayed presentation; posttraumatic; traumatic diaphragmatic injury.

\section{AMAÇ}

Travma sonrası gözden kaçan diyafram yaralanmaları karın içi organların toraksa fitıklaşması ile sonuçlanabilir. Bu çalışmada, travma sonrası gecikmiş diyafram yaralanması nedeniyle tedavi edilen hastalar değerlendirildi.

\section{GEREÇ VE YÖNTEM}

2001-2009 yılları arasında travma sonrası geç bulgu veren diyafram hernisi tanısı alan hastaların dosyaları geriye dönük olarak incelendi.

\section{BULGULAR}

Çalışmaya alınan 10 hastanın yaş ortalaması 44,3 yıl idi. Hastaların altısı kadındı. Etyolojide künt travma daha sık $(n=7)$ olarak saptand1. Travma ile travma sonrası diyafram hernisi tanısıyla hastaneye başvuru arasında geçen süre ortalama 5,9 y1l (4 ay-19 y1) idi. Dokuz hastada diyafram hernisi soldaydı. Tüm hastaların arka-ön akciğer grafisi çekildi ve çoğunda sadece grafi ile tanı kondu $(n=8)$. Yedi hastada ilave olarak bilgisayarlı tomografi ve manyetik rezonans görüntüleme kullanıldı. Herni tamiri için yedi hastada laparotomi iki hastada torakotomi yapılırken, bir hastada sol torakoabdominal insizyon kullanıldı. Onarım için yedi hastada yama kullanıldı. Ameliyat sonrası ortalama hastanede kalış süresi 10,6 gündü. Bir hastada ampiyem ve atelektazi saptand1. Ameliyat sonrası mortalite saptanmadi.

\section{SONUÇ}

Travma sonrası geç bulgu veren diyafram hernisi travma cerrahları için ciddi bir problemdir. Tanı ve tedavinin doğru ve hızlı uygulanması fitıklaşmış organların perforasyon veya gangreni sonrası gelişebilecek morbidite ve mortaliteyi engeller.

Anahtar Sözcükler: Diyafram hernisi; gecikmiş tanı; travma sonrası; travmatik diyafram yaralanması.

\footnotetext{
${ }^{1}$ Department of General Surgery, Gaziosmanpasa University, Faculty of Servisi, ${ }^{3}$ Göğüs Cerrahisi Servisi, İstanbul. 
Traumatic diaphragmatic injury is a serious condition associated with severe blunt and penetrating trauma. It has been detected more commonly in recent times owing to the advancement of diagnostic modalities and the awareness of medical staff. However, it still poses a great dilemma for trauma surgeons. The incidence has been reported as approximately $2 \%$ in blunt trauma and between $9-42 \%$ in penetrating thoracoabdominal trauma. ${ }^{[1-3]}$ Acute diaphragmatic injuries are mostly associated with multiple organ injuries. ${ }^{[4-6]}$ The mortality was related with the initial presentation of the patient and severity of hemorrhagic shock rather than the diaphragmatic injury itself. ${ }^{[6]}$

The diagnosis of isolated diaphragmatic injury is difficult since the early clinical and radiological findings are not clear. It is usually made on the table during operation. However, in some patients, there is risk of missing the diagnosis even in the operation..$^{[7,8]} \mathrm{In}$ recent decades, with the institution of nonoperative management, the diagnosis rather depends on a high level of suspicion and sophisticated diagnostic modalities. Unrecognized patients with diaphragmatic injury may present later in life with a great variety of symptoms ranging from vague dyspepsia and dyspnea to incarceration and perforation due to herniated abdominal organs into the thoracic cavity. The true incidence of delayed diagnosis of diaphragmatic injury is unknown. However, a recent study indicated that $2.7 \%$ of diaphragmatic injuries were detected after four months. ${ }^{[9]}$ The literature about the management of delayed diaphragmatic hernia consists mainly of sporadic cases and very few well-documented but limited case series. ${ }^{[7,10,11]}$ Since these case series are more than a decade old, the use of sophisticated diagnostic modalities such as multislice computerized tomography (CT) and magnetic resonance imaging (MRI) in delayed presentation has not been evaluated. Moreover, with the progress in postoperative patient care, morbidity and mortality have been improved.

Here, we aimed to present our management of delayed diaphragmatic injuries with the emphasis on diagnosis and the patient outcome.

\section{MATERIALS AND METHODS}

Patients treated in Vakif Gureba Training and Research Hospital between 2001 and 2009 with the diagnosis of delayed posttraumatic diaphragmatic hernia were reviewed. The study was approved by the institutional board of our hospital. Three patients with acute abdominal symptoms were reported earlier ${ }^{[12]}$ Delayed presentation of posttraumatic diaphragmatic hernia was defined as the diaphragmatic hernia not detected during the initial hospitalization after the trauma. The medical records of patients were reviewed for the demographic data, mechanism of injury, clinical presentation, diagnostic modalities, operations, and the outcome.

\section{RESULTS}

During the specified time, 10 patients were treated for delayed presentation of posttraumatic diaphragmatic hernia. The mean age of patients was 44.3 years (range: 20-78 years). Six patients were female. Blunt trauma was predominant, in 7 cases, while 3 cases had penetrating injuries. The mean duration between trauma occurrence and the delayed presentation to the hospital was 5.9 years (range: 4 months - 19 years). Nine patients had left and 1 patient had right diaphragmatic hernia. Three patients were admitted with mechanical intestinal obstruction symptoms. Five patients had respiratory symptoms like dyspnea with varying severity as their main complaints and 4 patients had abdominal pain. The initial diagnostic work-up was chest X-ray for all patients, and it was diagnostic in 8 patients (Fig. 1), whereas it was recorded as atypical in 2 patients. Additional imaging with CT and MRI was used in 7 patients. Both CT and MRI detected the diaphragmatic hernia with preoperative diagnosis of $100 \%$ (Fig. 2). Laparotomy was chosen for 7 patients as the surgical incision. Two patients underwent thoracotomy, whereas in 1 patient, a thoracoabdominal approach was necessary. The most common herniated organ was the colon $(n=7)$. Stomach and omentum were herniated in 5 patients, spleen in 4 patients, small bowel in 2 patients, and left kidney in 1 patient. Herniated organs were reduced in 9 patients without resection. One patient underwent colon resection due to microperforation. The mean diameter of the defect in the diaphragm after reduction was 7.4

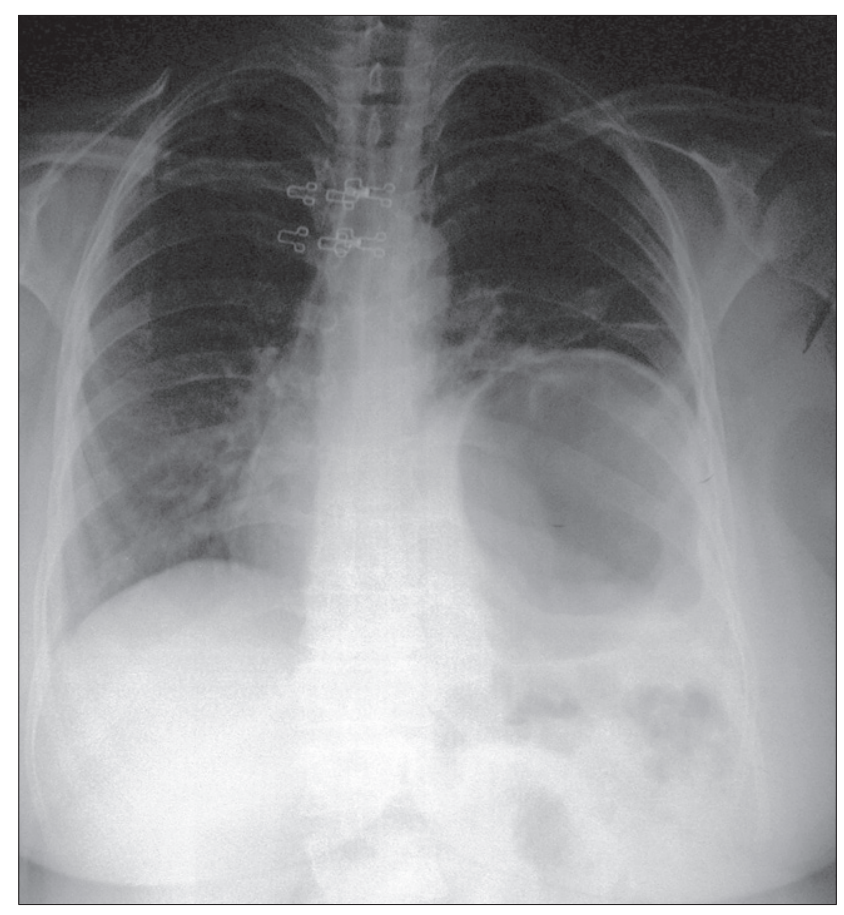

Fig. 1. A diagnostic posteroanterior chest X-ray of a patient presenting with vague abdominal pain one year after penetrating thoracoabdominal injury. 


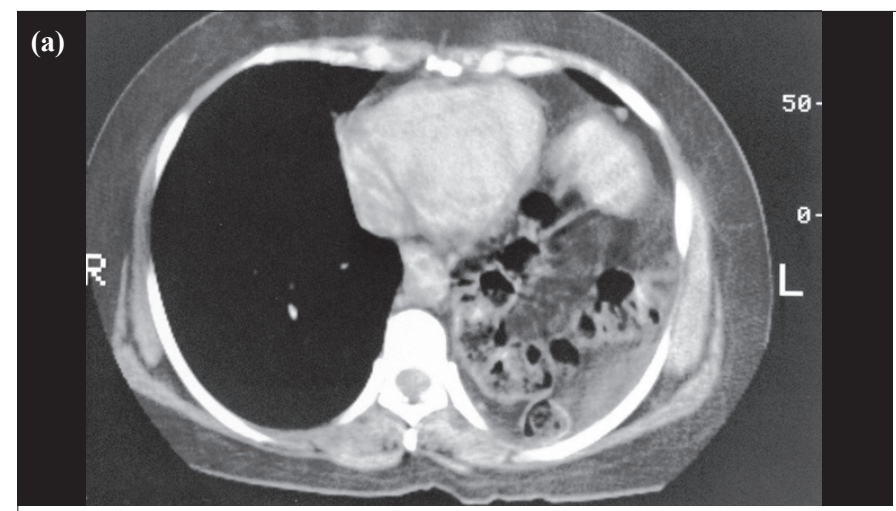

Fig. 2. (a) An abdominal CT scan of a patient with a history of blunt trauma 15 years ago, showing the presence of colonic segments in the left pleural cavity. (b) Magnetic resonance image of the patient with a penetrating trauma history of 19 years. The herniated organs through the defect in the left hemidiaphragm are noted.

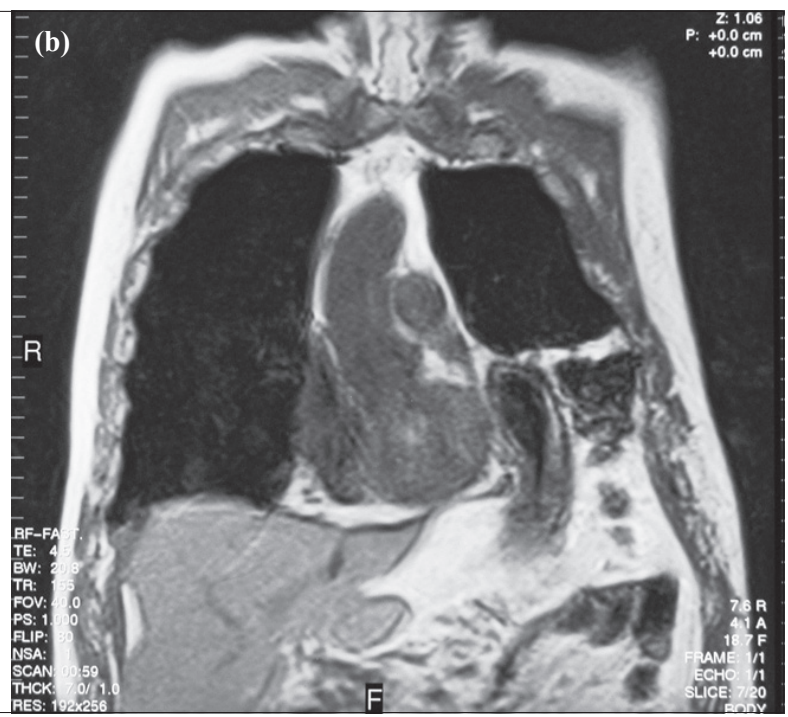

$\mathrm{cm}$ (range: 2-10 cm). Primary repair was used in 3 patients. While Prolene mesh was used in 5 patients, special meshes $\left(\operatorname{Bard}^{\circledR}\right.$ Composix ${ }^{\circledR}$ mesh, Davol Inc., UK) were used in 2 patients. Iatrogenic spleen injury resulting in splenectomy was recorded as the only perioperative complication, in 1 patient. Postoperative mean hospitalization of patients was 10.6 days $( \pm 4.4$ days). During hospitalization, there were two morbidities with empyema and atelectasis in the same patient, who was treated with percutaneous drainage and proper antibiotics. There was no postoperative mortality. Characteristics of patients are summarized in Table 1.

\section{DISCUSSION}

Diaphragmatic injury after trauma has been well recognized for centuries although the exact number of cases is unknown. The incidence may change according to trauma mechanism, location of injuries, and the modalities used for detection. Early reports are mainly based on findings in laparotomy, since most trauma patients had associated multiple injuries in addition to the diaphragmatic injury requiring surgery. Diaphragmatic injury was detected in $1.3 \%$ of patients with an Injury Severity Score of $>15$ on admission to a trauma center ${ }^{[9]}$ Small isolated injuries of the diaphragm may go unrecognized especially in patients nonoperatively treated after penetrating injuries of thoracic and abdominal traumas. Indeed, the use of laparoscopy in hemodynamically stable asymptomatic patients with thoracoabdominal wound detects diaphragmatic injury with an incidence of nearly $20 \%$ in some studies. ${ }^{[13,14]}$ Concerning the specific location of the wound in the body, the diaphragmatic injury was found as high as $42 \%$ in patients with left thoracoabdominal injuries detected by either laparotomy or laparoscopy. ${ }^{[3]}$ Due to the high incidence of diaphragmatic injury in left thoracoabdominal penetrating trauma, diagnostic laparoscopy is strongly recommended to exclude the possibility of isolated diaphragmatic injury otherwise unnoticed by conventional diagnostic modalities such as ultrasonography (US) and CT.

Almost half of the cases herniated through the diaphragmatic tear in the acute phase. Herniation is more common in the left hemidiaphragm with blunt trauma. ${ }^{[9]}$ If it goes undetected, the patient enters a relatively symptom-free period lasting from months to years. The delayed presentation is the last period when patients present with chronic abdominal or respiratory symp-

Table 1. Demographic features, clinical findings, diagnosis, and management of patients

\section{Patients}

Number (n) 10

Age (mean) 44.3

Gender (M/F) $4 / 6$

Hospitalization time (mean, day)

10

Time interval between trauma and operation (year)

Mechanism of injury (Blunt: Penetrating)

5.9

$7 / 3$

Presenting symptoms

Acute abdomen

(Mechanic intestinal obstruction, perforation)

Respiratory

Abdominal pain

Localization (L:R)

Diameter (cm, mean)

\section{5}

4

$9 / 1$

Chest X-ray

Diagnostic

Atypical

Additional radiologic imaging (CT, MR)

Incision

Laparotomy

Thoracotomy

Both

Organ resection (Colon)

Complication (Splenic injury)

\section{7}

2

$1(10 \%)$

1 
toms and/or obstructive signs. ${ }^{[1]]}$ The obstruction can be associated with strangulation and/or perforation of the herniated contents. However, the natural history of the diaphragmatic injury is unknown in most cases. For years, it has been stated that any injuries to the diaphragm result in diaphragmatic hernia owing to the pressure gradient between the thoracic and abdominal cavities and to the mobile nature of the diaphragm. Recently, some animal studies have challenged the thought with the findings that the diaphragm can heal without development of hernia. ${ }^{[15,16]}$ Clearly, the studies cannot be extended to humans. However, the scarcity of reports raises the possibility that some small injuries especially in the right diaphragm might not proceed to hernia.

Nearly all hernias were on the left side, possibly due to the protective effect of the liver on the right diaphragm. The only patient with right-sided diaphragmatic hernia was a 59-year-old female with a history of blunt trauma (fall from height) 15 years ago. The patient had symptoms of chronic cough and pain. During the operation, a diaphragmatic defect of $8 \mathrm{~cm}$ was detected, through which the hepatic flexure of the colon was herniated. Primary repair of the diaphragm was performed to restore the defect. Herniation in most of our cases followed blunt trauma. The two cases of penetrating abdominal wounds were stab wounds and one case was due to gunshot. Although trauma dates were old and their first admission was not to our clinic, it is logical to say that the use of diagnostic laparoscopy in stab wounds during the first admission might have prevented the occurrence of delayed left-sided diaphragmatic hernia.

In acute settings, the initial chest X-ray is diagnostic in only one-fourth of patients $(25 \%)$ due to interfering hemopneumothorax. ${ }^{[9]}$ This figure can be doubled with the attending radiologist's reading of the X-ray films.
CT scan could add $10 \%$ to the preoperative diagnosis. ${ }^{[9]}$ Since the diaphragmatic injuries due to blunt trauma are more prone to hernia development in the acute setting, it may be easier to detect the injuries preoperatively after blunt trauma. A recent report with the use of multidetector CT in penetrating diaphragmatic injuries has shown promising results, with sensitivity, specificity and accuracy rates of $87 \%, 72 \%$ and $77 \%$, respectively. ${ }^{[17]}$ Although chest X-ray findings in delayed presentation were more diagnostic than in acute admission in this study and in others, ${ }^{[10]}$ since most patients without acute symptoms had long-term complaints, additional diagnostic tests other than chest X-ray were routinely used. While older case series used upper gastrointestinal (GI) contrast studies, ${ }^{[11]}$ recent reports commonly used CT or MRI. ${ }^{[18,19]}$ With additional imaging, the rate of preoperative diagnosis in our patients with delayed diaphragmatic hernia without obstructive symptoms reaches $100 \%$. Therefore, if the patient's clinical situation allows some time to perform additional diagnostic tests, further tests like CT or MRI should be performed to achieve the correct diagnosis and plan the operation.

The choice of incision for the repair also differs in acute and delayed admission of diaphragmatic hernia. Most authors agreed on the transabdominal approach in acute injuries owing to the high incidence of associated abdominal injuries. ${ }^{[9,20,21]}$ However, in chronic hernias, some authors, referring to the strong adhesions between the herniated viscera and pleura, advocated thoracotomy. ${ }^{[7]}$ The disadvantage of thoracotomy is the requirement of additional laparotomy if the small or large bowel has to be resected. On the contrary, some authors used transabdominal approach with great success. ${ }^{[10]}$ It seems that the choice of incision is a matter of personal preference and expertise, since adhesion take-

Table 2. Comparative analysis of patient characteristics and their management with previous reports

\begin{tabular}{|c|c|c|c|c|}
\hline & Hegarty et al. ${ }^{[11]}$ & Feliciano et al. ${ }^{[7]}$ & Reber et al. ${ }^{[10]}$ & Present study \\
\hline Number (n) & 25 & 7 & 10 & 10 \\
\hline Time between operation and trauma (mean) & $\begin{array}{c}\text { NA (5 months- } \\
8 \text { years })\end{array}$ & $\begin{array}{c}1 \text { year }(8.5-14 \\
\text { years })\end{array}$ & $\begin{array}{c}4.1 \text { years }(20 \\
\text { days- } 28 \text { years) }\end{array}$ & $\begin{array}{c}5.9 \text { years }(4 \\
\text { months-19 years) }\end{array}$ \\
\hline Mechanism of injury (Blunt:Penetrating) & $3: 22$ & $7 *$ & $8: 2$ & $7: 3$ \\
\hline Localization (L:R) & $24: 1$ & $7: 0$ & $8: 2$ & $9: 1$ \\
\hline Additional radiology & $\begin{array}{c}\text { Upper } \\
\text { gastrointestinal } \\
\text { contrast study }\end{array}$ & $\begin{array}{l}\text { Upper } \\
\text { gastrointestinal } \\
\text { contrast study }\end{array}$ & $\begin{array}{c}\text { Upper } \\
\text { gastrointestinal } \\
\text { contrast study, } \\
\text { scintigraphy, CT }\end{array}$ & CT, MRI \\
\hline Repair type & Primary & Primary & Primary & $\begin{array}{c}3: 7 \\
\text { Primary: Mesh }\end{array}$ \\
\hline Morbidity & $\begin{array}{l}\text { 2:25 (empyema } \\
\text { and fecal fistula) }\end{array}$ & $\begin{array}{c}5: 7 \\
\text { (empyema, } \\
\text { pneumonia, } \\
\text { wound infection) }\end{array}$ & None & $\begin{array}{l}\text { 2:10 (empyema } \\
\text { and atelectasis) }\end{array}$ \\
\hline Mortality & $5: 25(20 \%)$ & None & $1: 10(10 \%)$ & None \\
\hline
\end{tabular}

\footnotetext{
* Included only penetrating injuries.
} 
down was successful with both options. We preferred mainly a transabdominal approach with the exception of three patients. One patient required additional thoracotomy after laparotomy for iatrogenic spleen injury during the operation due to the dense adhesions.

The preferred method of closure of the defect in our series was to use prosthetic material, contrary to the published case series. ${ }^{[7,10,11]}$ Table 2 compares the main characteristics of earlier reports and the present study. The reason for discrepancies could be due to the defect size and the duration, since both may cause the loss of elasticity of the diaphragm. The mean diameter of the defect was $7.4 \mathrm{~cm}$ in this series, and the mean duration was longer than in the above-mentioned studies. Indeed, in recent reports, the use of prosthetic mesh was readily favored. ${ }^{[22,23]}$

There was no mortality in our series. We had one complication of spleen injury during the operation and two postoperative morbidities with empyema and atelectasis. Clearly, the mortality rates of acute injury (7\%-28\%) differ from those of delayed diaphragmatic hernia. ${ }^{[1,9,24,25]}$ In the former situation, the presence of shock, brain injury (only in blunt trauma) and Injury Severity Score of $>15$ determine the mortality. ${ }^{[9]}$ Indeed, isolated diaphragmatic injuries in the absence of other surgical injuries were associated with low mortality. ${ }^{[6,24,25]}$ The reported mortality rates of delayed diaphragmatic hernia have changed in recent decades attributable to the earlier diagnosis and the improved postoperative patient management, decreasing from $25 \%$ to $10 \%{ }^{[10,11]}$ Recent case reports have reported low mortality rates in the treatment of delayed diaphragmatic hernias. ${ }^{[12,19]}$ However, the presence of strangulation with gangrene and perforation was related with increased morbidity and mortality. ${ }^{[11]}$

In conclusion, the delayed presentation of diaphragmatic hernia necessitates prompt awareness of the surgeon since the symptoms are usually vague and the trauma history is remote. Earlier diagnosis with the use of sophisticated radiologic modalities prevents the major morbidity and mortality associated with complications of diaphragmatic hernia like gangrene and perforation.

\section{REFERENCES}

1. Chughtai T, Ali S, Sharkey P, Lins M, Rizoli S. Update on managing diaphragmatic rupture in blunt trauma: a review of 208 consecutive cases. Can J Surg 2009;52:177-81.

2. Leppäniemi A, Haapiainen R. Occult diaphragmatic injuries caused by stab wounds. J Trauma 2003;55:646-50.

3. Murray JA, Demetriades D, Cornwell EE 3rd, Asensio JA, Velmahos G, Belzberg $\mathrm{H}$, et al. Penetrating left thoracoabdominal trauma: the incidence and clinical presentation of diaphragm injuries. J Trauma 1997;43:624-6.

4. Ward RE, Flynn TC, Clark WP. Diaphragmatic disruption secondary to blunt abdominal trauma. J Trauma 1981;21:35-8.

5. Shah R, Sabanathan S, Mearns AJ, Choudhury AK. Traumatic rupture of diaphragm. Ann Thorac Surg 1995;60:1444-9.

6. Williams M, Carlin AM, Tyburski JG, Blocksom JM, Harvey
EH, Steffes CP, et al. Predictors of mortality in patients with traumatic diaphragmatic rupture and associated thoracic and/ or abdominal injuries. Am Surg 2004;70:157-63.

7. Feliciano DV, Cruse PA, Mattox KL, Bitondo CG, Burch JM, Noon GP, et al. Delayed diagnosis of injuries to the diaphragm after penetrating wounds. J Trauma 1988;28:1135-44.

8. Clarke DL, Greatorex B, Oosthuizen GV, Muckart DJ. The spectrum of diaphragmatic injury in a busy metropolitan surgical service. Injury 2009;40:932-7.

9. Hanna WC, Ferri LE, Fata P, Razek T, Mulder DS. The current status of traumatic diaphragmatic injury: lessons learned from 105 patients over 13 years. Ann Thorac Surg 2008;85:1044-8.

10. Reber PU, Schmied B, Seiler CA, Baer HU, Patel AG, Büchler MW. Missed diaphragmatic injuries and their longterm sequelae. J Trauma 1998;44:183-8.

11. Hegarty MM, Bryer JV, Angorn IB, Baker LW. Delayed presentation of traumatic diaphragmatic hernia. Ann Surg 1978;188:229-33.

12. Alimoglu O, Eryilmaz R, Sahin M, Ozsoy MS. Delayed traumatic diaphragmatic hernias presenting with strangulation. Hernia 2004;8:393-6.

13. Powell BS, Magnotti LJ, Schroeppel TJ, Finnell CW, Savage SA, Fischer PE, et al. Diagnostic laparoscopy for the evaluation of occult diaphragmatic injury following penetrating thoracoabdominal trauma. Injury 2008;39:530-4.

14. Friese RS, Coln CE, Gentilello LM. Laparoscopy is sufficient to exclude occult diaphragm injury after penetrating abdominal trauma. J Trauma 2005;58:789-92.

15. Gamblin TC, Wall CE Jr, Morgan JH 3rd, Erickson DJ, Dalton ML, Ashley DW. The natural history of untreated penetrating diaphragm injury: an animal model. J Trauma 2004;57:989-92.

16. Zierold D, Perlstein J, Weidman ER, Wiedeman JE. Penetrating trauma to the diaphragm: natural history and ultrasonographic characteristics of untreated injury in a pig model. Arch Surg 2001;136:32-7.

17. Bodanapally UK, Shanmuganathan K, Mirvis SE, Sliker CW, Fleiter TR, Sarada K, et al. MDCT diagnosis of penetrating diaphragm injury. Eur Radiol 2009;19:1875-81.

18. Walchalk LR, Stanfield SC. Delayed presentation of traumatic diaphragmatic rupture. J Emerg Med 2010;39:21-4.

19. Eren S, Kantarci M, Okur A. Imaging of diaphragmatic rupture after trauma. Clin Radiol 2006;61:467-77.

20. Murray JA, Demetriades D, Asensio JA, Cornwell EE 3rd, Velmahos GC, Belzberg H, et al. Occult injuries to the diaphragm: prospective evaluation of laparoscopy in penetrating injuries to the left lower chest. J Am Coll Surg 1998;187:626-30.

21. Demetriades D, Kakoyiannis S, Parekh D, Hatzitheofilou C. Penetrating injuries of the diaphragm. Br J Surg 1988;75:824-6.

22. Seket B, Henry L, Adham M, Partensky C. Right-sided posttraumatic diaphragmatic rupture and delayed hepatic hernia. Hepatogastroenterology 2009;56:504-7.

23. Palanivelu C, Rangarajan M, Rajapandian S, Amar V, Parthasarathi R. Laparoscopic repair of adult diaphragmatic hernias and eventration with primary sutured closure and prosthetic reinforcement: a retrospective study. Surg Endosc 2009;23:978-85.

24. Bergeron E, Clas D, Ratte S, Beauchamp G, Denis R, Evans $\mathrm{D}$, et al. Impact of deferred treatment of blunt diaphragmatic rupture: a 15-year experience in six trauma centers in Quebec. J Trauma 2002;52:633-40.

25. Sözüer EM, Ok E, Avşaroğullari L, Küçük C, Kerek M. Traumatic diaphragmatic ruptures. Ulus Travma Derg 2001;7:176-80. 